\title{
Unique DNA plasmid pRS64 associated with chromosomal DNAs of the plant pathogenic fungus Rhizoctonia solani
}

\author{
Tadayuki Wako, ${ }^{1}$ Tatsuo Ishikawa ${ }^{2}$ and Teruyoshi Hashiba ${ }^{1 *}$ \\ ${ }^{1}$ Faculty of Agriculture, Tohoku University, 1-1 Tsutsumidori Amamiyamachi, Sendai 981, Japan \\ ${ }^{2}$ School of Science and Engineering, Teikyo University, Toyosatodai, Utsunomiya 320, Japan
}

(Received 10 June 1991; revised 8 August 1991; accepted 5 September 1991)

\begin{abstract}
Unique DNA sequences homologous to the linear DNA plasmid pRS64 were investigated in chromosomal DNAs of isolates belonging to anastomosis group 4 (AG-4) of the plant pathogenic fungus Rhizoctonia solani. Chromosome-sized DNAs of isolates RI-64 and 1271 of AG-4 were separated into six bands by orthogonal-fieldalternation gel electrophoresis and hybridized to a cloned segment of pRS64. A small chromosome-sized DNA band of approximately 1.1 Mb carried the sequences homologous to pRS64 DNA. Sequences homologous to pRS64 were also maintained within the chromosomal DNA of isolate 1271 of AG-4 which does not possess the plasmid. The plasmid showed no homology to the mitochondrial DNA of isolate 1271. The possibility that the linear plasmid pRS64 may act as a transposable genetic element is discussed.
\end{abstract}

\section{Introduction}

Rhizoctonia solani Kühn is a plant pathogenic fungus that has a wide host range and vegetative incompatibility in this fungus is determined by anastomosis (AG) and intraspecific (ISG) groups. Japanese isolates have been divided into nine AGs and ISGs. Plasmid DNAs designated pRS64-1, -2 , and -3 were detected in isolate RI-64 of AG-4. These were linear DNA plasmids of similar size $(2.7 \mathrm{~kb})$ (Hashiba, 1988; Miyashita et al., 1990). Linear plasmids have been detected in a wide variety of higher plants and fungi, including plant pathogenic fungi (as reviewed in Esser et al., 1986; Meinhardt et al., 1990; Sakaguchi, 1990), but knowledge as to the function of these genetic elements is still poor. Most linear plasmid DNAs have terminal proteins covalently attached to their $5^{\prime}$ termini. The terminal proteins have been shown to function as a primer for DNA replication. The pRS64 plasmid DNAs of $R$. solan $i$ have unique terminal structures: hairpin loops at both termini (Miyashita et al., 1990). Recently, we have found similar plasmid-like DNAs (plDNAs) in 48 isolates from nine AGs and ISGs of $R$. solani and showed that the plDNAs have considerable sequence homology between isolates within the same AGs and ISGs. However, no sequence homology was found among pIDNAs from

Abbreviations: AG, anastomosis group; ISG, intraspecific group; mtDNA, mitochondrial DNA; OFAGE, orthogonal-field-alternation gel electrophoresis; pIDNA, plasmid-like DNA. different AGs and ISGs. This suggested that the distribution of plDNAs correlated with the distinct host range of AGs and ISGs in $R$. solani (Miyasaka et al., 1990).

The mitochondrial DNA sequence of maize is known to share sequence homology with the linear plasmids S-1 and S-2. Moreover, sequences homologous to S-1 have been reported to occur in the maize nuclear genome (Kemble et al., 1983). However, in the plant pathogenic fungus Claviceps purpurea it has been reported that sequences homologous to plasmid $\mathrm{pCIK} 1$ were found to be integrated into high-molecular-mass mitochondrial DNA (mtDNA) (Tudzynski \& Esser, 1986). Oeser \& Tudzynski (1989) considered that the linear plasmid pCIK 1 and the $S$ plasmids belonged to a new class of ubiquitous mitochondrial plasmids with virus-like properties.

Here, we report the existence of chromosomal DNA sequences homologous to plasmid DNAs in isolates from AG-4 of $R$. solani.

\section{Methods}

\footnotetext{
Fungal isolates. $R$. solani isolates RI-64 and 1271 , belonging to AG-4 were used in this study. The isolate RI-64 containing the linear plasmid pRS64, was obtained from soil infected by the strongly pathogenic isolate 1271, which carries no plasmid (Hashiba et al., 1984). Cultures were grown and maintained on potato/sucrose agar medium $\left(\mathrm{g} \mathrm{l}^{-1}\right.$ : potato, 200; sucrose, 20; agar, 20).
} 
Preparation of intact chromosomal DNA. Protoplasts were prepared from $R$. solani using a modified method of Hashiba \& Yamada (1982). One gram (fresh weight) of the mycelium grown for $30-36 \mathrm{~h}$ in potato/sucrose liquid medium containing polypeptone was harvested on a $150 \mu \mathrm{m}$ steel sieve, washed with distilled water, and suspended in $10 \mathrm{ml}$ pretreatment solution containing 5 mM-EDTA (pH 8.0) and $0.2 \%$-mercaptoethanol at room temperature. After $1 \mathrm{~h}$, the mycelia were washed with distilled water, and resuspended in $10 \mathrm{ml} 0.6 \mathrm{M}-\mathrm{KCl}$ containing an enzyme mixture: $20 \mathrm{mg}$ cellulase $\mathrm{ml}^{-1}$ ('Onozuka' RS; Yakult Biochemical Co.), $10 \mathrm{mg}$ driselase $\mathrm{ml}^{-1}$ (Kyowa Hakko Co.), $0.4 \mathrm{mg}$ Novozyme $234 \mathrm{ml}^{-1}$ (Novo Enzyme Products) and $0.1 \mathrm{mg}$ chitinase $\mathrm{T}-\mathrm{I} \mathrm{\textrm {ml } ^ { - 1 }}$ (Asahi Industries $\mathrm{Co}$.). The culture flask was placed on a reciprocal shaker set at 75 strokes $\min ^{-1}$ at $34^{\circ} \mathrm{C}$ for $4 \mathrm{~h}$. The culture was then filtered through a $150 \mu \mathrm{m}$ steel sieve to remove the mycelial fragments, and the filtrate was centrifuged at least twice at $700 \mathrm{~g}$ for $5 \mathrm{~min}$ to remove the enzymes. The pellet was suspended in $0.5 \mathrm{ml} 0.6 \mathrm{M}-\mathrm{KCl}$ to a final concentration of approximately $2 \times 10^{8}$ protoplasts $\mathrm{ml}^{-1}$. An equal volume of $2 \%(\mathrm{w} / \mathrm{v})$ low-melting-point agarose in $0.6 \mathrm{M}-\mathrm{KCl}$ was added to the sample, and then the agarose plugs were incubated in a solution containing $1 \mathrm{mg}$ proteinase $\mathrm{K} \mathrm{ml}^{-1}$, $1 \%(\mathrm{w} / \mathrm{v})$ Sarkosyl and $0.45 \mathrm{M}$-EDTA (pH 9.0) for $24 \mathrm{~h}$ at $50^{\circ} \mathrm{C}$. These plugs were then stored in $0.5 \mathrm{M}$-EDTA $(\mathrm{pH} 8.0)$ at $4{ }^{\circ} \mathrm{C}$.

Preparation of total DNA. Mycelia were grown without shaking in polypeptone/potato/sucrose liquid medium. After 1-2 weeks, mycelia were harvested on a paper filter and lyophilized. Total cellular DNAs were prepared using the procedure of Hirt (1967) as modified by Miyashita et al. (1990).

Isolation of nuclear and mitochondrial DNA. Mitochondrial and nuclear DNAs were separated using a modification of the procedure of Garber \& Yoder (1983). CsCl (4.6 g) was dissolved in $4 \mathrm{ml}$ total DNA solution (containing 100-200 $\mu \mathrm{g}$ DNA). Bisbenzimide $(60 \mu \mathrm{l})$ was added from a $10 \mathrm{mg} \mathrm{ml}^{-1}$ stock solution. Tubes were centrifuged at $165000 \mathrm{~g}$ for $23 \mathrm{~h}$ at $20^{\circ} \mathrm{C}$, and following slow deceleration, at $100000 \mathrm{~g}$ for $48 \mathrm{~h}$. Bands of DNA were gently removed by side puncture of the tube with a needle. After centrifugation, the bisbenzimide was removed from each DNA band by extracting several times with isopropanol. DNA fractions were precipitated with ethanol and dissolved in Tris/EDTA (TE) buffer.

Isolation of mitochondria. The mycelium was harvested and ground with glass beads at $4{ }^{\circ} \mathrm{C}$ in 3 vols $0.5 \mathrm{M}$-mannitol, $50 \mathrm{mM}$-Tris $/ \mathrm{HCl}$ (pH 8.0), $5 \mathrm{~mm}$-EDTA, $1 \mathrm{~mm}$-2-mercaptoethanol and $0.1 \%$ BSA until a fine suspension was formed. Mitochondria were isolated from the suspension as described by Day \& Hanson (1977). The isolated mitochondria were treated with DNAase and RNAase at room temperature for $30 \mathrm{~min}$ to remove extra-mitochondrial DNA and RNA.

Cloning of fragments of pRS64 plasmids. pRS64 plasmid DNAs prepared as described previously (Miyashita et al., 1990) were digested with Xhol. Fragments of 2.2 and $1.5 \mathrm{~kb}$ from pRS64-1 and -2 , respectively, were ligated into pUC19. The ligation mixture was used to transform Escherichia coli JM109. Plasmid DNAs of Ampr $\mathrm{Lac}^{-}$ transformants were used as probes for Southern hybridization.

Orthogonal-field-alternation gel electrophoresis (OFAGE). OFAGE was performed using a $1 \%(\mathrm{w} / \mathrm{v})$ agarose gel in $0.5 \times$ TBE buffer $(1 \times$ TBE is $90 \mathrm{~mm}$-Tris/ $\mathrm{HCl}, 90 \mathrm{~mm}$-boric acid, $2.5 \mathrm{~mm}$-EDTA), cooled to $8-10{ }^{\circ} \mathrm{C}$, as described by Carle \& Olson (1984). Gels were run for about $120 \mathrm{~h}$ at $3 \mathrm{~V} \mathrm{~cm}^{-1}$ with a 60 min switching interval, followed by $48 \mathrm{~h}$ at $3 \mathrm{~V} \mathrm{~cm}^{-1}$ with a $2 \mathrm{~min}$ switching interval. The gels were then stained with $1 \mu \mathrm{g}$ ethidium bromide $\mathrm{ml}^{-1}$ for $20 \mathrm{~min}$ and destained in $0.5 \times$ TBE for $20 \mathrm{~min}$.

Southern hybridization. Agarose gels containing chromosomal DNAs were hydrolysed by acid depurination prior to alkali denaturation, then transferred to nylon membrane filters. DNA probes were prepared by labelling with $\left[\alpha^{32} \mathrm{P}\right] \mathrm{dCTP}$ using the multipriming labelling system (Amersham). Nylon membranes were hybridized for $16-24 \mathrm{~h}$ at $42^{\circ} \mathrm{C}$ in $25 \%(\mathrm{v} / \mathrm{v})$ formamide, $6 \times \mathrm{SSC}, 100 \mu \mathrm{g}$ denatured salmon sperm DNA ml-1, $5 \times$ Denhardt's solution and $0.5 \%(\mathrm{w} / \mathrm{v}) \operatorname{SDS}(1 \times \mathrm{SSC}$ is $0.15 \mathrm{M}-\mathrm{NaCl}, 0.015 \mathrm{M}$-sodium citrate, $\mathrm{pH} 7.0 ; 1 \times$ Denhardt's solution is $0.02 \%$ Ficoll, $0.02 \%$ bovine serum albumin, $0.02 \%$ polyvinylpyrollidone). Hybridization patterns were visualized by autoradiography. All procedures were carried out as described by Maniatis et al. (1982).

\section{Results}

\section{Mitochondrial location of plasmid DNAs}

To investigate the location of plasmid DNAs of $R$. solani AG-4, total DNAs or DNA isolated from intact mitochondria were separated by $\mathrm{CsCl}$-bisbenzimide centrifugation. Plasmid bands were found only in the mtDNA fractions (Fig. 1). After DNAase treatment of intact mitochondria, the plasmids were still present, indicating their mitochondrial location.

\section{Separation of chromosomal DNAs by OFAGE}

We have modified the procedure of Hashiba \& Yamada (1982) to prepare high yields of protoplasts from $R$. solani. This procedure yields $3 \times 10^{7}$ protoplasts per $\mathrm{g}$ (fresh weight) of mycelia. Chromosomal DNAs of both isolates, RI-64 and 1271, were efficiently released from protoplasts and subjected to OFAGE. Using $1 \%$ agarose gels and pulse intervals of $60 \mathrm{~min}$ and $2 \mathrm{~min}$ for periods of 120 and $48 \mathrm{~h}$, respectively, both the RI-64 and 1271 genomes were resolved into six distinct bands (Fig. 2a).

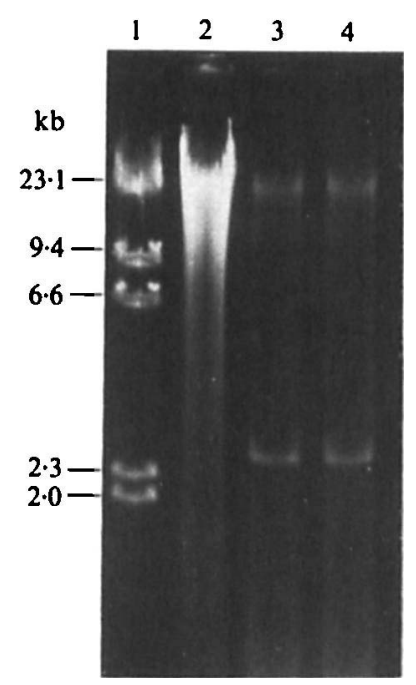

Fig. 1. Electrophoretic analysis of nuclear and $m t D N A$ fractions from CsCl-bisbenzimide-purified DNA and DNA isolated from intact mitochondria of isolate RI-64 from $R$. solani AG-4. Lanes: 1, $\lambda$ DNA digested with HindIII; 2, DNA from nuclear fraction; 3, DNA from mitochondrial fraction; 4, DNA isolated from intact mitochondria. 


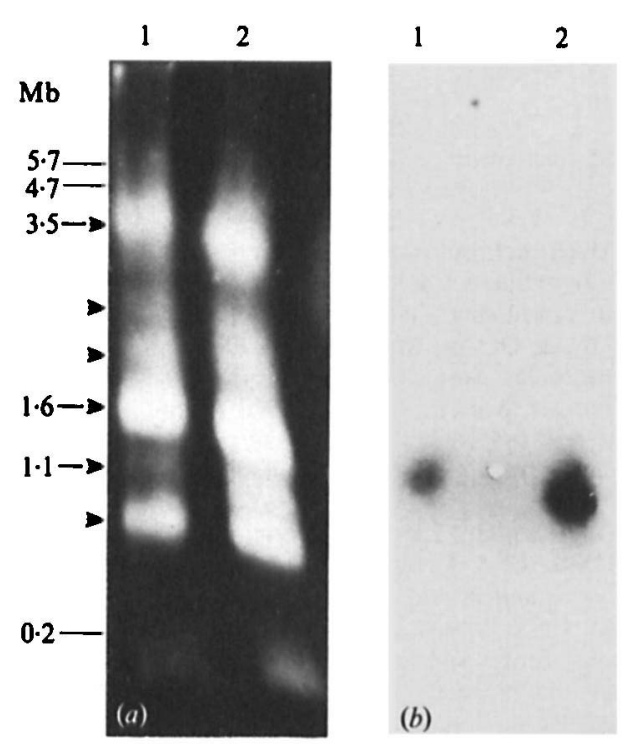

Fig. 2. Southern blot of $R$. solani chromosomal DNA separated by OFAGE. (a) Maximal separation of the largest DNA fragments; initial run of $120 \mathrm{~h}$ with $60-\mathrm{min}$ pulse at $3 \mathrm{~V} \mathrm{~cm}-1$ followed by $48 \mathrm{~h}$ with 2 -min pulse at $3 \mathrm{~V} \mathrm{~cm}^{-1}$. (b) Southern blot of chromosomal DNA and probed with pRS64 DNA. Lanes: 1 , isolate $1271 ; 2$, isolate RI-64. Arrow heads indicate chromosomal DNA bands of $R$. solani. The estimated sizes of the chromosomes in the electrophoretic bands from Saccharomyces cerevisiae and Schizosaccharomyces pombe are indicated on the left.

The sizes of these six bands were $0 \cdot 8,1 \cdot 1,1 \cdot 6,1 \cdot 8,2 \cdot 5$ and $3.8 \mathrm{Mb}$, respectively, as estimated by reference to the chromosomal DNAs of Saccharomyces cerevisiae and Schizosaccharomyces pombe.

\section{Sequence homology of pRS64 DNA to chromosomal DNAs}

As the $R$. solani isolate RI-64 carried the pRS64 plasmids, but 1271 , the isolate from which it was derived, did not, the relationship between plasmid DNA and chromosomal DNAs in mycelia of these isolates was investigated. Cloned DNA fragments of pRS64 were hybridized to electrophoretically separated chromosomal DNAs. As can be seen in Fig. 2(b), hybridization was restricted to a single band of $1 \cdot 1 \mathrm{Mb}$, suggesting the presence of a unique chromosomal position of the integrated plasmid DNA in both isolates.

\section{Detection of a unique nuclear sequence}

To test the possibility of integration of the plasmid DNAs in either nuclear or mitochondrial DNAs, the labelled fragment of pRS64 was hybridized to nuclear and mitochondrial DNAs of isolate 1271 digested to completion with BamHI and EcoRI. Several fragments of the nuclear DNA hybridized with the probe of cloned pRS64 DNA (Fig. 3). The sizes of these fragments obtained by restriction with BamHI and EcoRI ranged from 8.8 to $2.8 \mathrm{~kb}$ and from 8.4 to $3.6 \mathrm{~kb}$, respectively. When mtDNA of isolate 1271 was digested with BamHI and $E c o$ RI, no homology between fragments of mtDNA and pRS64 was observed (Fig. 3).

\section{Discussion}

Analysis of total DNA in field isolates of $R$. solani AG-4 showed that half the isolates (8 out of 18) contained plDNA (Miyasaka et al., 1990). Analysis of mtDNA showed that all of the 15 isolates from $R$. solani AG-4 except isolate 1271 contained pIDNA (unpublished data). Furthermore, we also detected plasmid bands only in mitochondrial fractions. After DNAase treatment of intact mitochondria, the plDNAs proved resistant, indicating their mitochondrial location. However, these
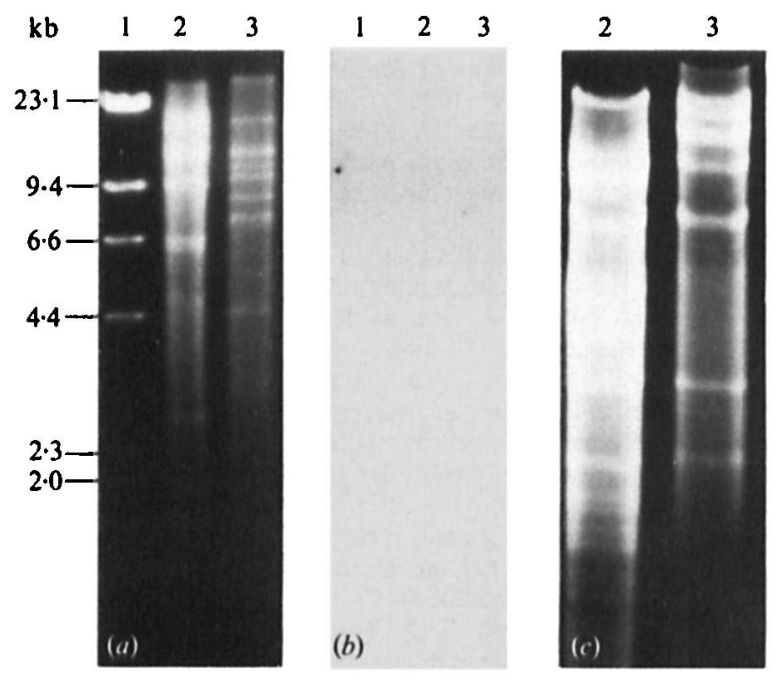

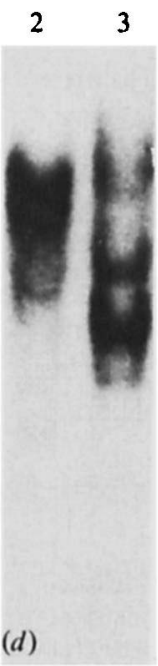

Fig. 3. Detection of a unique nuclear sequence. $(a, c)$ Gel-electrophoretic analysis of restriction enzyme digests of mitochondrial $(a)$ and nuclear $(c)$ DNAs from isolate 1271. $(b, d)$ Results of hybridization of Southern transfer strips from $(a)$ and $(c)$, respectively, with cloned pRS64 DNA probes. Lanes: 1, ADNA digested with HindIII; 2, nuclear and mitochondrial DNA digested with BamHI; 3, nuclear and mitochondrial DNA digested with EcoRI. 
experiments do not rule out the possibility that the plDNA exists extra-mitochondrially in the cytoplasm as well as within mitochondria.

To gain information on the chromosomal DNA of $R$. solani, we have applied the technique of OFAGE to separate large DNAs from the filamentous fungus. At least six chromosome-sized DNA bands from $R$. solani could be separated by OFAGE. In this way the total genome size of $R$. solani is estimated to be more than $11 \mathrm{Mb}$. The assignment of linkage groups to the resolved chromosomal DNA bands may be undertaken using linkage group-specific probes. The physical analysis of fungal genomes by OFAGE has been successful with other plant pathogenic fungi as an aid to karyotyping or genomic mapping (Kinscherf \& Leong, 1988; McCluskey \& Mills, 1990; Mills \& McCluskey, 1990; Rollo et al., 1989; Tzeng et al., 1989). Recently, chromosome length polymorphisms were observed among different races of Ustilago hordei (McCluskey \& Mills, 1990).

Fungal plasmids have been shown to share homology with either nuclear DNA (Wright \& Cummings, 1983) or mtDNA or both (Van den Boogaart et al., 1982; reviewed by Samac \& Leong, 1989). Southern hybridization analysis with nearly full-length clones of pRS64-1 and -2 (excluding the terminal regions) identified an homologous sequence within a $1.1 \mathrm{Mb}$ chromosomal DNA band. The cloned fragments of pRS64 shared sequence homology with nuclear DNA but not mtDNA from isolate 1271 . This suggests that pRS64 may well be stably integrated into the chromosomal DNA. DNA sequences homologous to plasmid pCIK 1 were found to be integrated at the $5^{\prime}$ end of the large rRNA gene within the mitochondrial genome of the plant pathogenic fungus Claviceps purpurea (Tudzynski \& Esser, 1986). Similar cases have been reported in other eukaryotes (Bertrand $e t$ al., 1985, 1986), and discussed in terms of linear DNA plasmids acting as transposable genetic elements.

We have shown that there is considerable sequence homology among plasmid DNAs obtained from isolates within the same AG and ISG of $R$. solani (Miyasaka et al., 1990). It is still to be determined whether the plasmids are actively transcribed and translated. Interesting questions arise as to how the plasmid sequences are maintained within the genomic DNA of isolate 1271, and how the plasmid DNAs may be excised and amplified in isolate RI-64. Equally it is possible that the integrated DNA sequences may play a role in plasmid expression.

The authors wish to sincerely thank Dr Y. Ehara for helpful suggestions. This work was supported by grants from the Ministry of Education, Science and Culture of Japan, and the Ministry of Agriculture, Forestry and Fisheries of Japan (BMP91-III-2-4).

\section{References}

Bertrand, H., Chan, B. B. S. \& Griffith, A. J. F. (1985). Isolation of a foreign nucleotide sequence into mitochondrial DNA causes sequence in Neurospora intermedia. Cell 41, 877-884.

Bertrand, H., Griffith, A. J. F., Court, D. A. \& Cheng, C. K. (1986). An extrachromosomal plasmid is the etiological precursor of kalDNA insertion sequence in the mitochondrial chromosome of senescent Neurospora. Cell 47, 829-837.

Carle, G. F. \& Olson, M. V. (1984). Separation of chromosomal DNA molecules from yeast by orthogonal-field-alternation-gel electrophoresis. Nucleic Acids Research 12, 5647-5664.

DAY, D. A. \& Hanson, J. B. (1977). On methods for the isolation of mitochondria from etiolated corn shoots. Plant Science Letters 11, 99-104.

Esser, K., KÜCK, U., Lang-Hinrichs, C., Lemke, P., Osiewacz, H. D., StAHL, U. \& TUdzYNSKI, P. (1986). Plasmids of Eukaryotes. Fundamentals and Applications. Heidelberg: Spring-Verlag.

GARBER, R. C. \& YODER, O. C. (1983). Isolation of DNA from filamentous fungi and separation into nuclear, mitochondrial, ribosomal and plasmid components. Analytical Biochemistry 135, 416-422.

HASHIBA, T. (1988). Role of linear DNA plasmids in plant pathogenic fungi. 5th International Congress of Plant Pathology, p. 12 (abstract).

Hashiba, T. \& Yamada, M. (1982). Formation and purification of protoplasts from Rhizoctonia solani. Phytopathology 72, 849-853.

Hashiba, T., Homma, Y., Hyakumachi, M. \& Matsuda, I. (1984). Isolation of a DNA plasmid in the fungus Rhizoctonia solani. Journal of General Microbiology 130, 2067-2070.

HIRT, B. (1967). Selective extraction of polyoma DNA from infected mouse cell culture. Journal of Molecular Biology 26, 365-369.

Kemble, R. J., Mans, R. J., Gabay-Laughnan, S. \& Laughnan, J. R. (1983). Sequences homologous to episomal mitochondrial DNAs in the maize nuclear genome. Nature, London 304, 744-747.

KinSCHERF, T. C. \& LEONG, S. A. (1988). Molecular analysis of the karyotype of Ustilago maydis. Chromosoma 96, 427-433.

Maniatis, T., Fritsch, E. F. \& Sambrook, J. (1982). Molecular Cloning: A Laboratory Manual. Cold Spring Harbor, NY: Cold Spring Harbor Laboratory.

MCCLUSKEY, K. \& MILLS, D. (1990). Identification and characterization of chromosome length polymorphisms among strains representing fourteen races of Ustilago hordei. Molecular Plant-Microbe Interactions 2, 155-159.

MeinhardT, F., Kempken, F., Kämper, F. \& Esser, K. (1990). Linear plasmids among eukaryotes: fundamentals and application. Current Genetics 17, 89-95.

MiLls, D. \& MCCluskeY, K. (1990). Electrophoretic karyotype of fungi : the new cytology. Molecular Plant-Microbe Interactions 3, 351357.

Miyasaka, A., Chen, C. L. \& Hashiba, T. (1990). Detection and properties of plasmid-like DNA in isolates from nine anastomosis and intraspecific groups of Rhizoctonia solani. Journal of General Microbiology 136, 1791-1796.

Miyashita, S., Hirochika, H., Ikeda, J. \& Hashiba, T. (1990). Linear plasmid DNAs of the plant pathogenic fungus Rhizoctonia solani with unique terminal structures. Molecular and General Genetics 220 , 165-171.

OESER, B. \& TUdzynski, P. (1989). The linear mitochondrial plasmid pCIK 1 of the phytopathogenic fungus Claviceps purpurea may code for a DNA polymerase and an RNA polymerase. Molecular and General Genetics 217, 132-140.

Rollo, F., Ferracuti, T. \& Pacilli, A. (1989). Separation of chromosomal DNA molecules from Phoma tracheiphila by orthogonal-field-alternation gel electrophoresis. Current Genetics 16, 477479.

SAKAGUCHI, K. (1990). Invertrons, a class of structurally and functionally related genetic elements that includes linear DNA plasmids, transposable elements, and genomes of adeno-type viruses. Microbiological Reviews 54, 66-74.

SAMAC, D. A. \& LeONG, S. A. (1989). Mitochondrial plasmids of filamentous fungi : characteristics and use in transformation vectors. Molecular Plant-Microbe Interactions 2, 155-159. 
TUDZYNSKI, P. \& ESSER, K. (1986). Extrachromosomal genetics of Claviceps purpurea. II. Plasmids in various wild strains and integrated plasmid sequence in mitochondrial genomic DNA. Current Genetics 10, 463-467.

Tzeng, T., Chang, H. \& Bronson, C. (1989). Electrophoretic confirmation of chromosome rearrangements in Cochliobolus heterostrophus. Phytopathology 79, 1173 (abstract).
Van den Boogaart, P., Samalls, J. \& Agsteribbe, E. (1982). Similar genes for a mitochondrial ATPase subunit in the nuclear and mitochondria genomes of Neurospora crassa. Nature, London 298, 187-189.

WRIGHT, R. M. \& Cummings, D. J. (1983). Integration of mitochondrial gene sequence within the nuclear genome during senescence in a fungus. Nature, London 302, 86-88. 